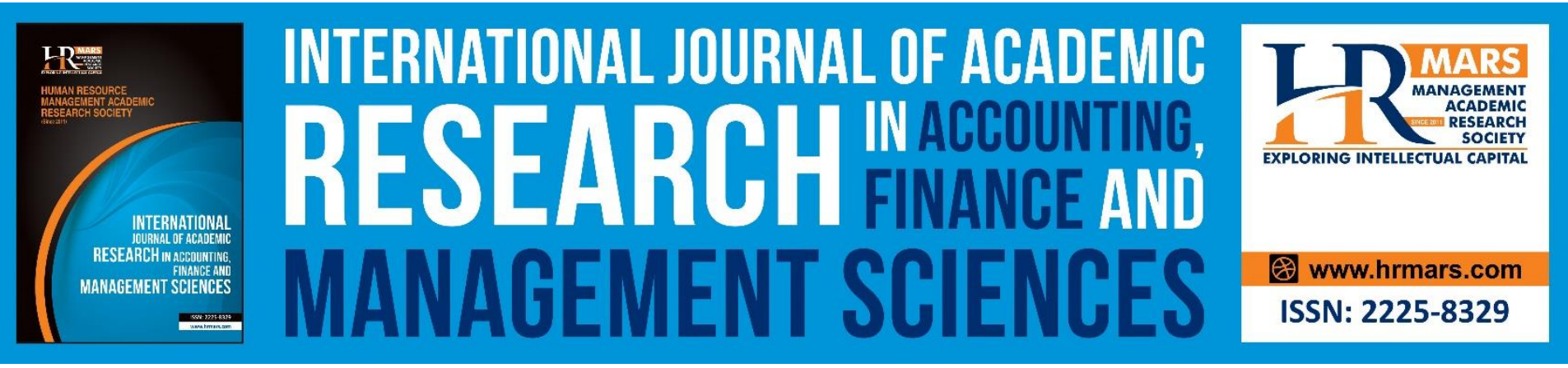

\title{
An Analysis on Asset Price Inflation: Impact of Expansionary Monetary Policy on Asset Purchasing Power
}

\author{
Ahmet Rutkay Ardogan, Remzi Can Yilmaz
}

To Link this Article: http://dx.doi.org/10.6007/IJARAFMS/v11-i3/10356

DOI:10.6007/IJARAFMS /v11-i3/10356

Received: 05 June 2021, Revised: 08 July 2021, Accepted: 27 July 2021

Published Online: 20 August 2021

In-Text Citation: (Ardogan \& Yilmaz, 2021)

To Cite this Article: Ardogan, A. R., \& Yilmaz, R. C. (2021). An Analysis on Asset Price Inflation: Impact of Expansionary Monetary Policy on Asset Purchasing Power. International Journal of Academic Research in Accounting Finance and Management Sciences, 11(3), 33-47.

Copyright: (C) 2021 The Author(s)

Published by Human Resource Management Academic Research Society (www.hrmars.com)

This article is published under the Creative Commons Attribution (CC BY 4.0) license. Anyone may reproduce, distribute, translate and create derivative works of this article (for both commercial and non-commercial purposes), subject to full attribution to the original publication and authors. The full terms of this license may be seen at: http://creativecommons.org/licences/by/4.0/legalcode

Vol. 11, No. 3, 2021, Pg. 33 - 47

Full Terms \& Conditions of access and use can be found at http://hrmars.com/index.php/pages/detail/publication-ethics 


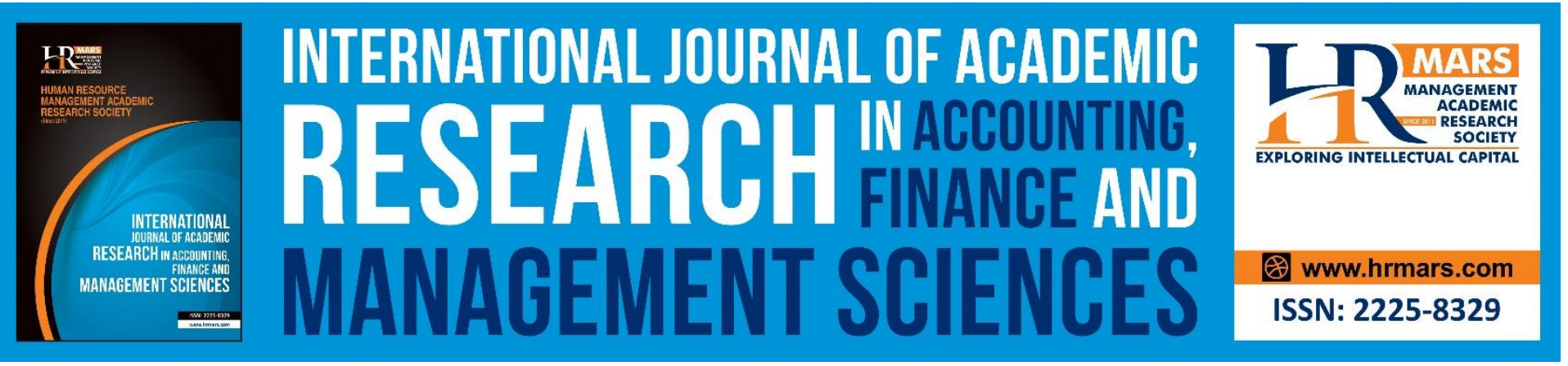

\title{
An Analysis on Asset Price Inflation: Impact of Expansionary Monetary Policy on Asset Purchasing Power
}

\author{
Ahmet Rutkay Ardogan, Remzi Can Yilmaz \\ Beykent University, Finance and Banking Department. \\ Email: rutkayardogan@beykent.edu.tr, canyilmaz@beykent.edu.tr
}

\begin{abstract}
In this study, we identify the monetary policy mechanisms that lead to inflation in asset prices in the 2011-2020 decade (post-2008 crisis and COVID19 period), by focusing on the relationship between increases in asset prices and disposable personal income. We run a panel data regression by using quarterly data from fourteen OECD countries, and by taking minimum wages as a proxy for disposable personal income, and stock market indices as a proxy for asset prices. We show that expansionary monetary policy - via M3 money supply and credits given to non-financial private sector - positively impacts equity prices, and even leads to equity price booms. Moreover, we show that individuals with low level of income faced a decrease in their asset purchasing power in this period, which is an important issue for central banks and monetary policy authorities to take into consideration. As a further research, a similar can be applied to all thirty-eight members of OECD, by distinguishing developed and developing countries, and focus on increases in different layers of income levels and different assets, such as housing.
\end{abstract}

Keywords: Asset Price Inflation, Monetary Policy, Stock Market, Global Financial Crisis

\section{Introduction}

After the 2008-2009 financial meltdown, the central banks' focus on price stability and domestic product deficits, while ignoring level of asset prices, caused controversy. In particular, the effects of asset price bubbles have drawn increased attention. As years passed by, the view that the central banks should react to the developments in the asset markets gained strength. Because of a suspicion on the possibility of an asset price bubble, the supporters of this view suggest that inflation and domestic product targets should be temporarily suspended in order to prevent asset price inflation that could cause bubbles. For instance, use of unconventional monetary policy tools in Euro area caused the prices to go up in equity and sovereign bond markets. The EuroStoxx 50 index witnessed an almost 24 percent points increase over six months starting three months before the European Central Bank's public announcement of bond purchases on January 2015, while the price of benchmark 10 year German Bund increases by 6 percentage points (Adam and Tzamourani, 2016). 
INTERNATIONAL JOURNAL OF ACADEMIC RESEARCH IN ACCOUNTING, FINANCE AND MANAGEMENT SCIENCES

Vol. 11, No. 3, 2021, E-ISSN: 2225-8329 @ 2021 HRMARS

Another example is from the USA: While the policy interest rates and consumer price index are in historical low levels, today S\&P 500 index is almost $200 \%$ higher than the level in 2011 . Final example is from monetary growth levels. The aggregate money supply of the world's twelve largest economies increased by $\$ 14$ trillion in 2020 , and now the total value is $\$ 94.8$ trillion, which is the largest annual increase in global money supply. Moreover, the balance sheets of the world's biggest central banks, the Federal Reserve, the European Central Bank, the Bank of Japan, and the Bank of England, reached to $54.3 \%$ level of their countries' GDP. This growth level may be described as tremendous, considering the level was 36\% at the end of 2019 and $10 \%$ in 2008.

Asset price inflation, meaning great changes in asset price levels, has many forms such as an inflation in art objects, land, housing purchases or equities (Schwartz, 2013). Economic literature generally suggests that changes in the traditional transmission channels of monetary policy leads to a change in asset prices' levels. In the monetary transmission mechanism, asset prices are in the process of affecting the real economy through the wealth effect channel. An outcome changes in monetary policy practices, asset prices change and total demand changes. As a result, output and inflation are affected (Cecchetti and Schoenholtz, 2006).

Although the ultimate goal of monetary authorities is price stability, policy makers' decisions are often influenced by only taking the consumer price index into account, hence excluding changes in asset prices in the process of achieving this goal. Consumer price index covers just a small portion of all goods and services in an economy, moreover has a very sticky structure. While the impact of the expansionary monetary policy on consumer prices may take up to ten years to fully show its effect, this period is reduced to a much shorter period, only six months in asset prices, thus these prices are considered to be highly flexible. Disregarding the asset prices index and acting on the rigid consumer price index may cause monetary authorities to misinterpret the current economic situation and thus implement wrong policy practices (Andersson, 2011).

In this study, we aim to give insights to a possible asset price inflation and its determinants in fourteen OECD countries between 2011 and 2020. We suspect that changes in monetary practices, especially after 2008 crisis, did not have a significant effect on consumer price indexes, however caused an asset price inflation, leading to a decrease in asset purchasing power of individuals, whose disposable personal income increased less than asset prices. By focusing on quarterly panel data, the effects of expansionary monetary and credit policies, and minimum wages on movements in equity market indexes, a proxy for asset prices, are examined. By using minimum wages as a proxy of disposable personal income, we also aim to show how equally the financial stimulus and relief packages are distributed among the population, after 2008-2009 global financial crisis and during COVID 19 pandemic.

Next section focuses on briefly summarizing the literature on asset price inflation and its determinants. In the third section, illustration of graphical analyses and an empirical analysis between asset price inflation, monetary policy decisions and wage levels is studied. Final section consists discussion and concluding remarks.

\section{Literature Review}

As the financial liberalization and innovation globally progressed in the World, the latter fifty years of the twentieth century witnessed asset prices becoming a very important factor in determining economic fluctuations. For instance, asset prices act as an information source for market expectations, risk levels, or as an early indicator of inflation, output, and market shocks. Due to all 
INTERNATIONAL JOURNAL OF ACADEMIC RESEARCH IN ACCOUNTING, FINANCE AND MANAGEMENT SCIENCES

Vol. 11, No. 3, 2021, E-ISSN: 2225-8329 ๑ 2021 HRMARS

these reasons, asset prices' movements have become more important for policymakers, in order to analyze and interpret the signals, and transform into policy decisions. On the other hand, policymakers should note that movements in asset prices effect a small portion of the individuals. To back this claim, Adam and Tzamourani (2016) show that bond and equity price increases do not have any effect positive on three quarters of the population. Increases in equity prices cause net wealth inequality to ascend, while an increase in bond prices has no effect on net wealth inequality in Euro area. Despite its larger effect on population, an increase in house prices benefits middle and upper middle class' net wealth distribution. An unexpected monetary tightening leads to an almost five times more gain for the $5 \%$ richest households, in comparison to remaining households.

After the 2008-2009 global financial crisis, a debate on whether central banks should be more reactionary to asset price movements has begun. For example, Assenmacher-Wesche and Gerlach (2009) investigate the effects of monetary policy shocks on inflation, residential property, economic activity and equity prices. The results show that monetary policy effects on property prices is three times as large as its effect on GDP. Thorbecke (1997), by using the changes in federal funds rate and nonborrowed reserves are as monetary policy variables, show that expansionary monetary policy increases ex-post stock returns. The study also shows that the implementation of monetary policy increases the ex-ante return of an asset.

Bordo and Wheelock (2004) examine the U.S. stock market booms in the past. According to the results, rapid real growth and productivity advance takes part in the creation of booms. Moreover, they cannot provide any significant links between inflation and stock market booms. Instead, the study suggests that above average growth in money and credit seems to cause asset price booms. In a similar vein, Congdon (2005) stresses on the importance of broad money, suggesting that additional funds spur additional demand for assets. Geromichalos, Licari and SuarezLledó (2007) also show a significant positive link between monetary policy and asset prices. Another study, conducted by Andersson (2011), investigates the relationship of monetary expansion with consumer price index, GDP deflator, stock price index and house price indices. The study reveals that monetary policy shocks are correlated with financial asset inflation in the short, medium and long term. Real asset price inflation and quantitative easing are correlated in the medium and long term, meanwhile monetary expansion and the consumer price index is only correlated in the long run. As a contradiction to the dominant view, Gali and Gambetti (2015), using the time-varying coefficients VAR method, conclude that the contractionary monetary policy increases the stock prices in the long run. Another study backing this claim is Yao, Luo and Loh (2013). By using Johansen's cointegration approach, they show that monetary policy has no large immediate effect on asset prices.

Apart from money growth rate, policy interest rates play an important role on asset prices, as well. For instance, Patelis (1997), using long-horizon regressions and short-horizon vector autoregressions, suggests that an increase in federal funds rate has a negative effect on expected stock returns in the short run. However, in longer periods, this effect becomes positive. Using a different approach, Bernanke and Kuttner (2005) measure the response of the securities markets to the FED's unexpected policy rate changes. According to their findings, a 25-basis-point cut in the federal funds rate leads to a 1 percent increase in stock indices. Rigobon and Sack (2004), by using an estimator based on the heteroskedacity seen in high-frequency data instead of an event-study approach, show that a rise in short-term interest rates lead to a decline in stock prices and a shrinking upward shift in the yield curve over longer maturities. Moreover, they state that the event-study approach, which is generally preferred type of study on this subject, leads to false results. 
INTERNATIONAL JOURNAL OF ACADEMIC RESEARCH IN ACCOUNTING, FINANCE AND MANAGEMENT SCIENCES

Vol. 11, No. 3, 2021, E-ISSN: 2225-8329 ๑ 2021 HRMARS

Low interest rates bring into play another important factor that may affect asset price inflation, the role of credits. Low interest rates encourage risk-taking behaviors, hence level of borrowing increases because only risky investments are profitable and credit is cheap, fostering leveraged booms (Dell'Ariccia et al., 2014). Moreover, policymakers may support those decisions, which lead financial institutions to supply more credits to the markets. As an example, Nelson (2003) suggest that strong credit growth is an indicator of a lax monetary policy, which leads to the creation of excessive liquidity in the markets, and leads to excessive price changes in the asset markets. Borio et. al (1994) show that the ratio of total private credit to nominal GDP provides significant information to predict movements in the real asset price index. Focusing on the linkages between credit aggregates and asset price imbalances in the stock market instability episodes in the euro area since the 1980s, Christiano et. al (2013) demonstrate a significant positive link between credit and asset price developments. Actually, Jorda et al. (2013) even claim that credit booms may lead to financial crises, via increasing the asset prices into bubble levels.

In summary, existing literature suggests that asset price inflation has different dynamics compared to consumer price developments, and is mainly influenced by monetary and credit expansionary policies. Thus, we build our model based on these foundations.

\section{Analysis}

\section{Data}

Minimum wage is chosen as a proxy for disposable personal income in this study. The reason behind this choice is to capture the purchasing power of individuals' earnings by work. Moreover, we believe that expansionary monetary policies benefit low-income classes less than higher income classes, thus minimum wage comparison may be a better indicator to measure asset price inflation. The minimum wage data used in the study is collected from the Organization for Economic Cooperation and Development (OECD.STAT) and the International Labor Organization (ILOSTAT).

Countries' main stock market index values are collected from Trading Economics webpage. In order to get a clearer picture of countries' money growth level, we use M3 as the monetary aggregate, since it is the broadest measure of money supply and defines money as a store of value. M3 money supply data is obtained from Federal Reserve Economic Data (FRED) and OECD.STAT. Domestic level of credits given to individuals and private sector are gathered from Bank of International Settlements (BIS). Central banks' policy interest rates data is collected from BIS, as well. Finally, consumer price index and real GDP per capita data are obtained from OECD.STAT.

All variables' values in this study are measured as quarterly percentage changes, in order to avoid a possible non-stationary process and to better capture changes in quarterly periods.

\section{Some Stylized Facts About Asset Price Boom}

Stock market indices have been following an upward trend since the end of the $2008 \mathrm{Global}$ Financial Crisis. According to our data, gathered from fourteen OECD countries, the level of equity prices are increasing much higher than the increase in minimum wage levels.

If we look at the data closely, and distinguish the countries based on being a developed or a developing country, we observe similar trends in both groups. Besides, on the left hand side, the graph of stock purchasing power of minimum wage in developed countries shows us is getting flatter in recent years, whereas it is gaining momentum in developing countries in the late years, as it can be seen on the right side. An interesting fact is that the sharp increase in developed countries slowed 
INTERNATIONAL JOURNAL OF ACADEMIC RESEARCH IN ACCOUNTING, FINANCE AND MANAGEMENT SCIENCES

Vol. 11, No. 3, 2021, E-ISSN: 2225-8329 @ 2021 HRMARS

down after Taper Tantrum in 2013, when the Fed announced future tapering of its quantitative easing program, which had started after 2008 crisis, in order to help the economy to get back on its feet. One can also figure out that the only drop in developed countries occurred in 2018, when the Fed increased its policy rate to the highest levels of the decade. In developing countries, increase in the stock market value / minimum wage level gathered pace after 2018, because of the Fed's change in high policy rate stance, and decreasing the policy rate level.

\section{Graph 1. Stock Market Value / Minimum Wage Ratio in Developed/Developing Countries, 2011/2020}
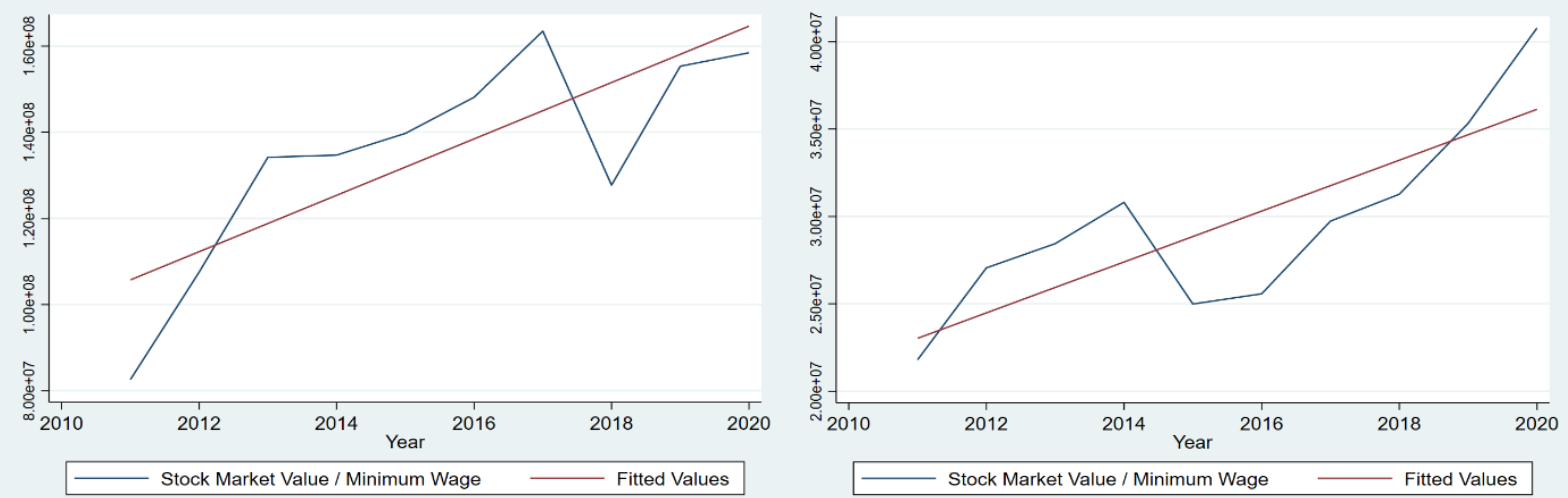

Another important comparison for checking a possible asset inflation in equity markets could be comparing the level of changes in average stock market value and minimum wages with inflation levels. The graph below shows us that average of stock market indices increased more than the average minimum wage and average inflation in the last ten years. In fact, while level of changes in stock market indices and minimum wage have increased, average inflation level has decreased, compared to the levels in ten years ago.

If we change the focus level to the country groups, we can observe a similar pattern. The graph on the left demonstrates that average yearly change of stock markets has been higher than both increases in minimum wages and inflation levels. The situation is more striking in developing countries: Stock markets has been increasing much higher than the other two. Another crucial point is that average inflation levels have been decreasing in both developed and developing countries.

Graph 2. Stock Markets Indices, Minimum Wage and Inflation Level Changes on Average in All, Developed and Developing Countries, 2011/2020

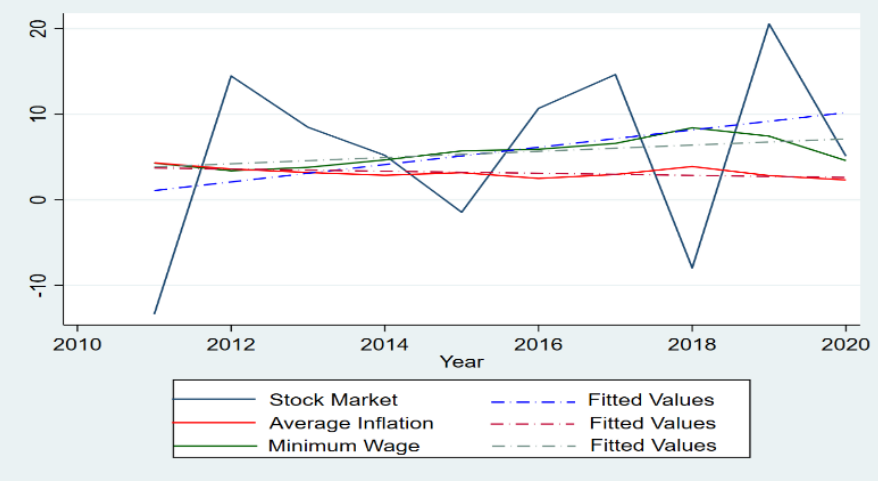


INTERNATIONAL JOURNAL OF ACADEMIC RESEARCH IN ACCOUNTING, FINANCE AND MANAGEMENT SCIENCES

Vol. 11, No. 3, 2021, E-ISSN: 2225-8329 @ 2021 HRMARS
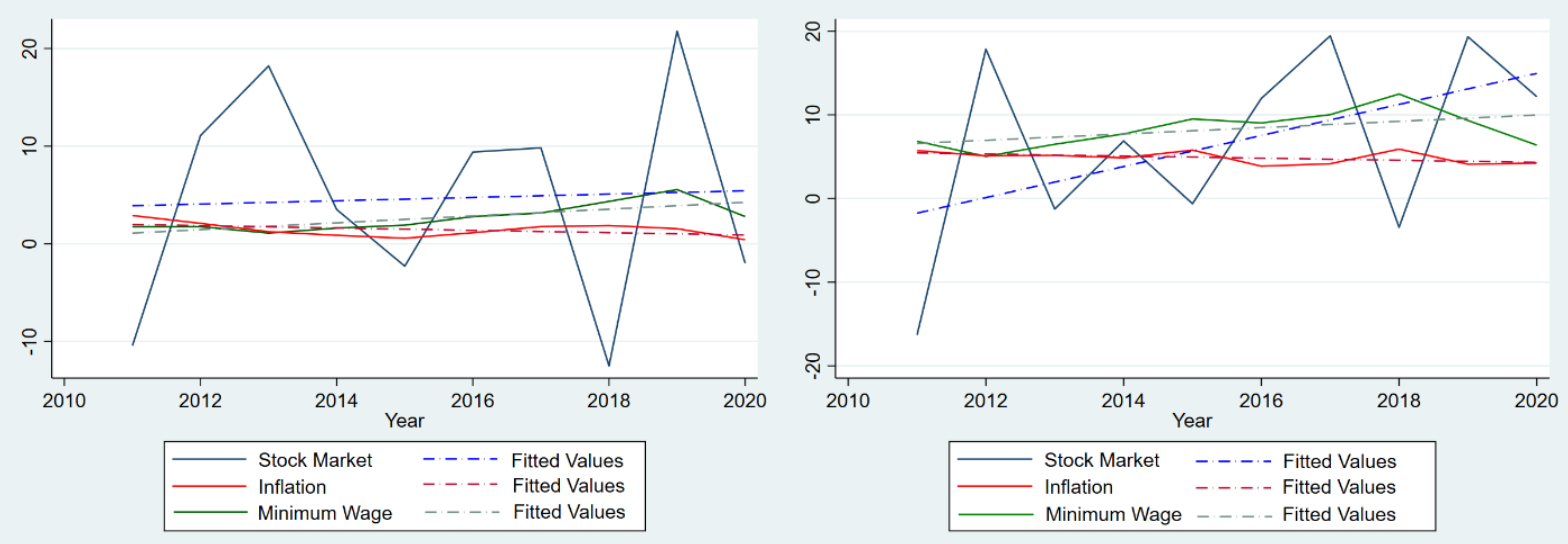

All graphs above show the possibility of an asset price inflation worldwide in the past decade. In order to get a clearer picture, we compare the ratio of average yearly change in stock market value / minimum wage with yearly inflation levels below.

As expected, average inflation level has been declining, from around $3.5 \%$ to $2.5 \%$, but an individual earning minimum wage is able to buy less stocks with his/her wage compared to a decade ago. We can see a similar outcome in the graphs below: Inflation trend is downward in both developed and developing countries, by around 1\%; however, the ratio of stock market value / minimum wage has been increasing in both country groups in the same period. The major difference between developed and developing countries is that the slope of the ratio of stock market value / minimum wage is steeper in the developed countries than the developing countries.

Graph 3. Stock Market Value / Minimum Wage Ratio and Inflation Level Changes in All, Developed and Developing Countries, 2011/2020

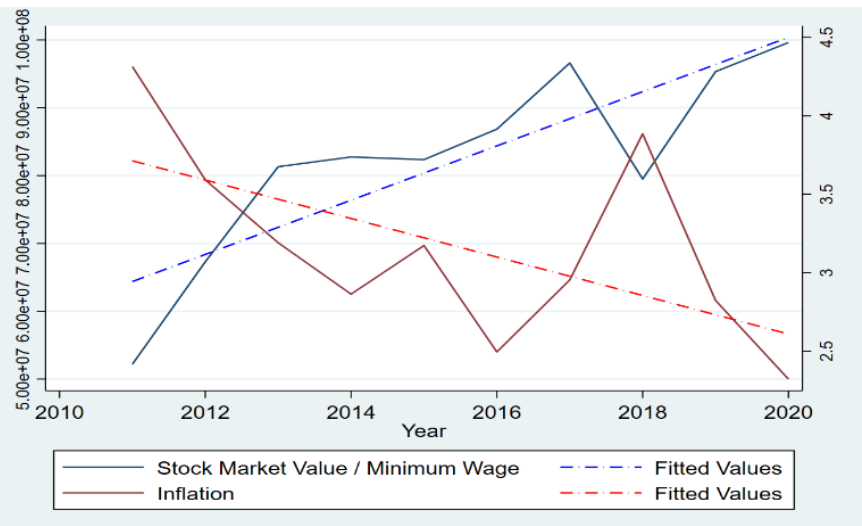


INTERNATIONAL JOURNAL OF ACADEMIC RESEARCH IN ACCOUNTING, FINANCE AND MANAGEMENT SCIENCES

Vol. 11, No. 3, 2021, E-ISSN: 2225-8329 @ 2021 HRMARS
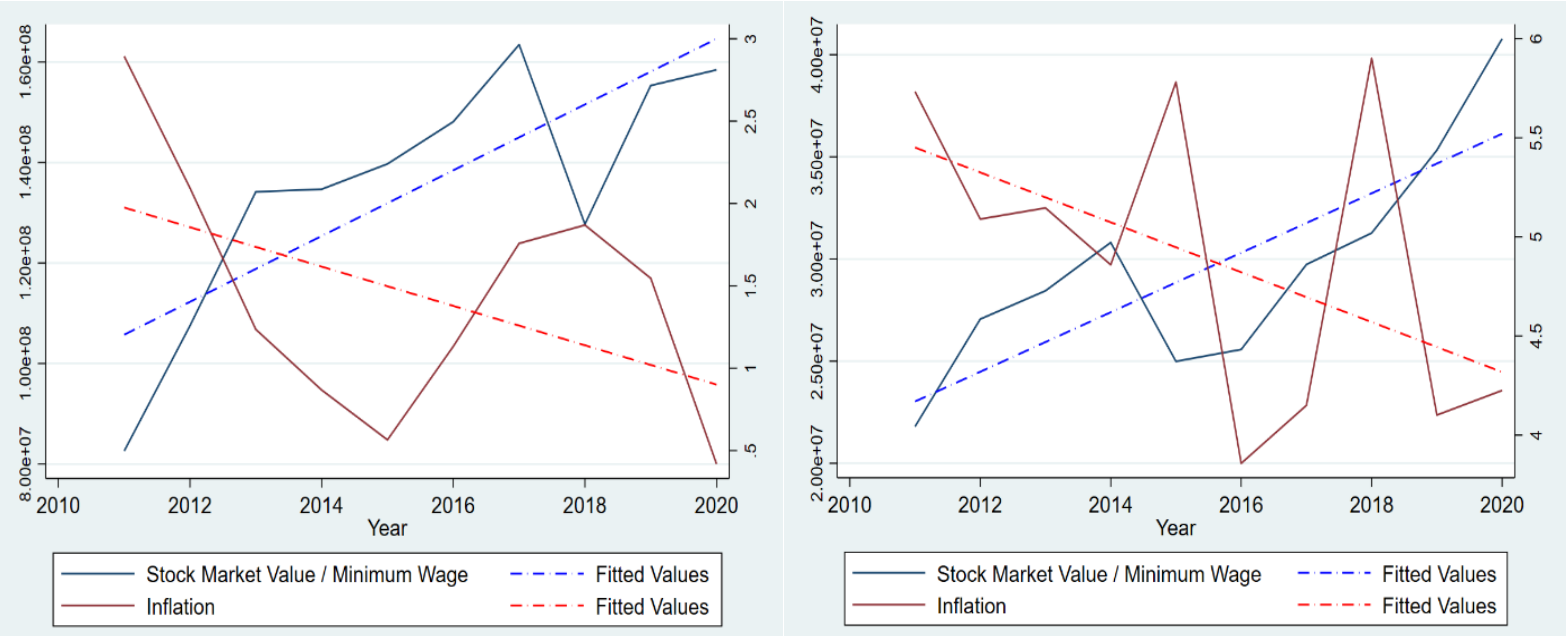

The documented movements in equity prices, inflation levels and level of minimum wages below show us that there has been a generalized upswing pattern, after the effects of 2008 global financial crisis was overcome. Most macroeconomics literature suggest that changes in monetary and credit conditions play a role in affecting asset price movements. Thus, the effects of money supply (M3) and credit supply (given to non-financial sector and individuals) should be analyzed, in order to better understand the dynamics of asset price inflation:

The graph below demonstrates us the average yearly level of change of M3 money supply in developed, developing and all countries. First of all, one can observe that developing countries had higher percentage changes in money supply than developed countries in the last decade. An important reason is that the developing countries had higher inflation levels, although this point cannot explain the observed gap solely. Another crucial observation is the sharp increase in average yearly changes in both developed and developing countries in 2020. This is an expected increase, owing to the monetary stimulus packages issued by the governments, in order to overcome the economic contraction because of the COVID-19 pandemic.

\section{Graph 4. M3 Money Supply Level Changes in Developed and Developing Countries, 2011/2020}

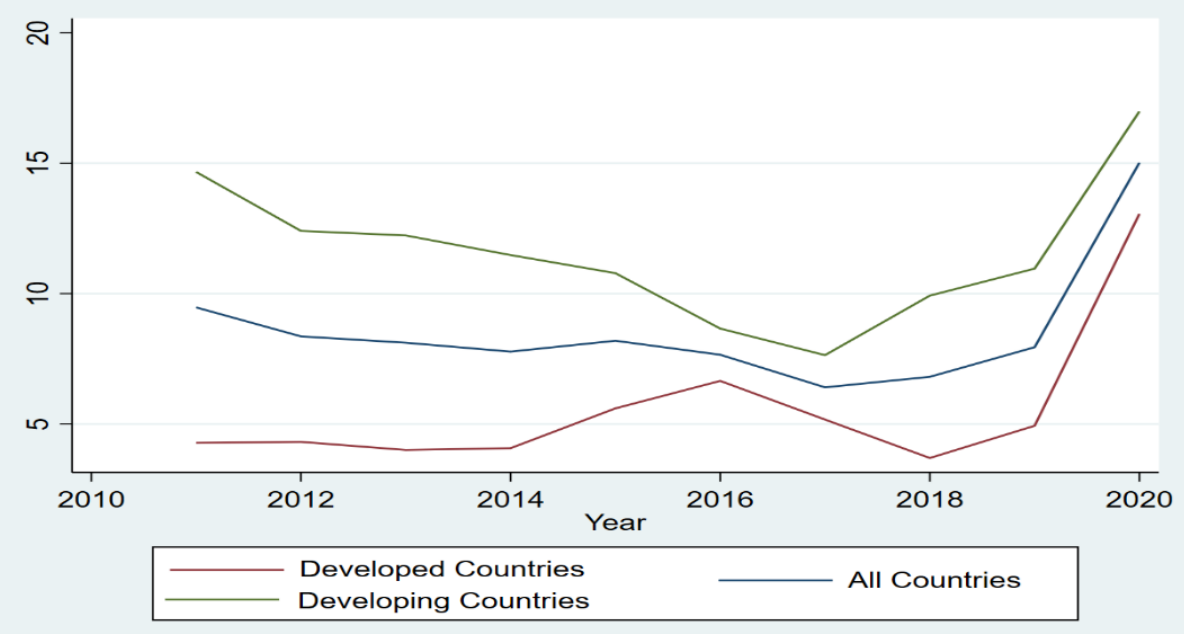

As mentioned above, another possible factor on asset price inflation is the amount of credits supplied to the markets. Below, we can see the historical movements of the amount of credits given 
Vol. 11, No. 3, 2021, E-ISSN: 2225-8329 @ 2021 HRMARS

to the non-financial sectors in the last decade. The graph, which shows the average yearly change rate of the credits to the non-financial sectors in between 2011-2020, in developed and developing countries, demonstrates that the developing countries had a higher rate until 2016. Since then, the average yearly change rates have been following similar paths in both country groups. Again, as we have seen with the M3 money supply data, there has been a sharp increase in the rates in 2020.Because the governments supported credit expansionary policies via low interest rates, vouching programs, guarantee funds etc., thus gave support to private sector and individuals (as we will see below), it led to a high increases in average yearly credit levels.

\section{Graph 5. Changes in the Level of Credit Given to Non-Financial Sector in Developed and Developing Countries, 2011/2020}

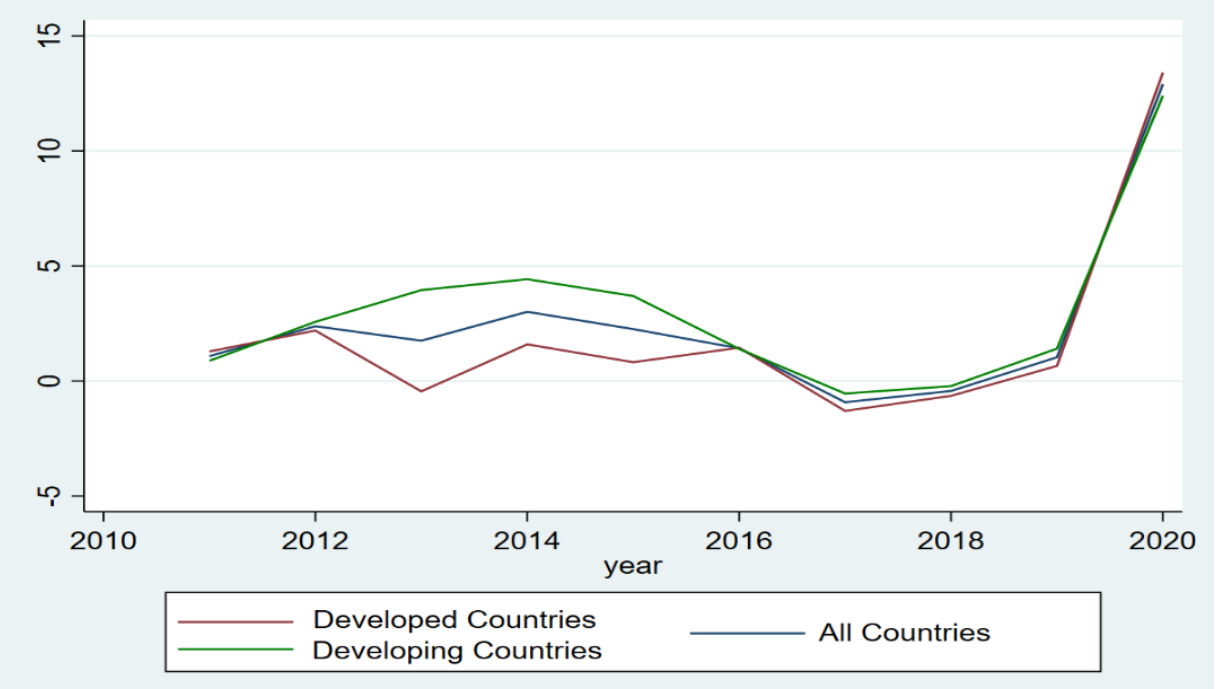

One last factor to analyze as a determinant of asset price inflation is the level of credits given to individuals/households. As in the case of the credits given to the non-financial sector, developing countries have historically higher rates in this category, as well. Actually, developed countries had below zero rates until 2020, almost consistently. That means the amount of credits given to individuals have been decreasing in developed countries. However, the situation changed dramatically in 2020, the average rate of change had a steep increase due to new economic policies in pandemic era, as explained above. 
INTERNATIONAL JOURNAL OF ACADEMIC RESEARCH IN ACCOUNTING, FINANCE AND MANAGEMENT SCIENCES

Vol. 11, No. 3, 2021, E-ISSN: 2225-8329 @ 2021 HRMARS

\section{Graph 6. Changes in the Level of Credit Given to Individuals and Households in Developed and Developing Countries, 2011/2020}

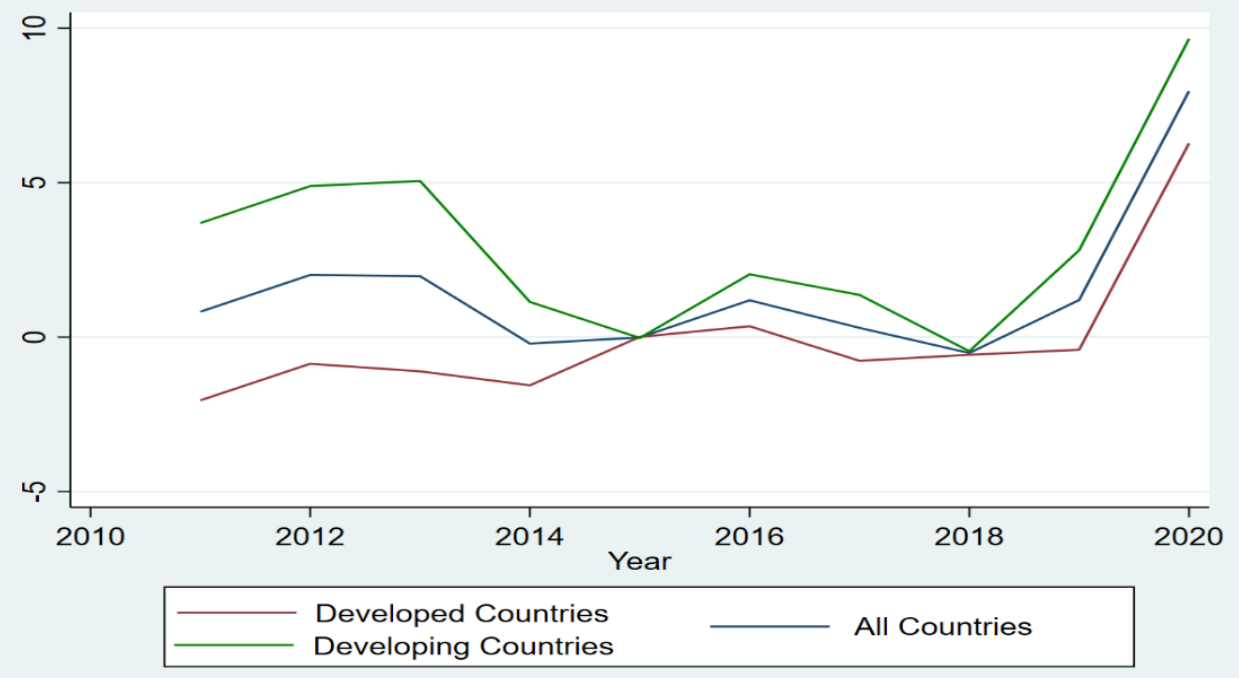

\section{Empirical Analysis}

In this section, the determinants affecting stock market prices are investigated, hence we aim to find out the factors leading to an asset price inflation in the last decade. As mentioned above, we suspect that upsurge in M3 money supply, credits given to non-financial sectors and credits given to individuals/households has led to the inflation in question. Moreover, we also aim to show that increases in minimum wages (a proxy for the disposable presonal income) has no significant effect on this surge.

Because our dataset is consisted of 10 years (40 quarters) data of 14 countries, we have the chance to apply panel data analysis to the data, by using Stata 16.0 statistical analysis software. Panel data regressions are estimated on quarterly data between Q1 2011 and Q4 2020.

In order to prevent a possible nonstationary data issue, and to get a better glimpse of the effects of quarterly changes, quarterly growth rates of variables are taken into account (except level of inflation).

To test the significance of mentioned determinants' effects on stock market indices, we suggest four hypotheses:

Hypothesis 1: Quarterly percentage changes in minimum wages does not affect level of percentage changes in equity market indices.

Hypothesis 2: Quarterly percentage changes in M3 money supply affect level of percentage changes in equity market indices.

Hypothesis 3: Quarterly percentage changes in credits given to non-financial sectors affect level of percentage changes in equity market indices.

Hypothesis 4: Quarterly percentage changes in credits given to individuals/households affect level of percentage changes in equity market indices.

Apart from the four independent variables, several control variables are identified for testing the hypotheses. Literature suggests that GDP, inflation rate, and the policy interest rate are the main exogenous factors determining stock market prices (Bruggeman (2006), Lee et al. (2006), Panigirtzoglou and Scammell (2002)). Therefore, we list the variables of the regression as below: 
- Dependent Variable

equityit= Quarterly \% change in stock market indices of a country

- Independent Variables:

M3 ${ }_{\text {it-1 }}=$ Quarterly \% change in M3 money supply of a country

nonfin_credit ${ }_{i t-1}=$ Quarterly \% change in credits given to non-financial sectors of a country indv_credit it-1 $_{\mathbf{1}}=$ Quarterly \% change in credits given to individuals/households of a country

min_wage it-1 $_{\text {- }}$ Quarterly \% change in minimum wage levels in a country

- Control Variables:

GDP $_{\text {it-1 }}=$ Quarterly \% change in GDP of a country

inflation $_{\text {it-1 }}=$ Quarterly $\%$ change in consumer price index in a country

equityit-1= Quarterly \% change in stock market indices of a country

interest_rate it-1 $_{1}=$ Quarterly \% change in policy interest rates in a country

Thus, the regression model can be derived as below, based on the variables listed above:

equity ${ }_{i t}=\beta_{0}+\beta_{1} M 3_{i t-1}+\beta_{2}$ nonfin_credit $_{i t-1}+\beta_{3}$ indv_credit $_{i t-1}+\beta_{4}$ min_wage e $_{i t-1}+\beta_{5}$ GDP ${ }_{i t-1}$

$+\beta_{6}$ inflation ${ }_{i t-1}+\beta_{7}$ equity ${ }_{i t-1}+\beta_{8}$ interest_rate ${ }_{i t-1}$

Where

$i=1,2, \ldots \ldots ., 14$ (Australia, Brazil,....., USA)

$t=2011 Q 1,2011 Q 2, \ldots \ldots \ldots, 2020 Q 4$

Estimation output of random-effects GLS regression, and significance levels are as follows:

equity $_{\mathrm{it}}=0.337+0.77 \mathrm{M} 3_{\mathrm{it}-1}+0.726$ nonfin_credit $_{\mathrm{it}-1}-0.149 \mathrm{indv}_{-} \mathrm{credit}_{\mathrm{it}-1}-0.022 \mathrm{~min} \_w a g \mathrm{i}_{\mathrm{it}-1}$

$(0.001)^{* *} \quad(0.002)^{* *} \quad(0.603) \quad(0.817)$

$+0.342 \mathrm{GDP}_{\mathrm{it}-1}-0.758$ inflation $_{\mathrm{it}-1}-0.267$ equity $_{\mathrm{it}-1}-0.016$ interest_rate $_{\mathrm{it}-1}$

$(0.007)^{* *} \quad(0.040)^{*} \quad(0.000)^{* *}$

(0.331)

${ }^{*} p<0.05 * * p<0.01 \quad\left(R^{2}=0.13 * *\right)$

Three of our four hypotheses are supported. The second hypothesis claims that a growth in M3 money supply significantly increases stock market indices. This hypothesis is supported in $99 \%$ confidence level, according to our estimation. Third hypothesis suggests that a growth in credits given to non-financial sectors significantly increases stock market indices. This hypothesis is also supported in $99 \%$ confidence level. We suggested in the fourth hypothesis that a growth in credits given to individuals/households significantly increases stock market indices. However, estimation results failed to support this hypothesis. Thus, we fail to show that credits given to the individuals/households have a positive effect on increases in equity prices. Lastly, we argued that raises in minimum wage does not have a significant effect on stock market indices in first hypothesis. In a similar vein, the results show that minimum wage increases indeed are insignificant on stock market indices increases.

\section{Discussion and Conclusion}

As a side effect of monetary policy response to the global financial crisis in 2008-2009, asset price inflation/bubble has become a hot debate topic in the finance world. Stimulus packages announced by governments, in order to overcome the economic recession caused by COVID-19 pandemic, have had a multiplying effect on this phenomenon. As a result, this subject has become a hot topic for researchers. 
INTERNATIONAL JOURNAL OF ACADEMIC RESEARCH IN ACCOUNTING, FINANCE AND MANAGEMENT SCIENCES

Vol. 11, No. 3, 2021, E-ISSN: 2225-8329 @ 2021 HRMARS

This paper examines the relationship of asset prices and disposable personal income after the global financial crisis, and tries to identify the monetary policy mechanisms that lead to inflation in asset prices. By using quarterly data from fourteen OECD countries in 2011-2020 period, we use minimum wages as a proxy for disposable personal income, and stock market indices (equity prices) as a proxy for asset prices.

Illustrated scatterplots demonstrate that equity prices followed an upward trend in the past decade, while consumer price index have been falling. More importantly, increases in minimum wages have not been as high as equity prices, thus the ratio of equity prices to minimum wages increased in a ten-year span, minimum wage earners faced with diminished equity purchasing power consequently. In addition, empirical analysis suggests that increases in minimum wages does not play a significant effect on equity prices growth.

The results presented above do show that expansionary monetary policy - that is having a high growth rate in M3 money supply or having a growth in credits given to non-financial private sector - does positively impact equity prices. However, one should also note that level of central banks' policy interest rates and growth rate of credits given to individuals/households did not play a significant role on equity prices in between 2011-2020. We also found that increase in GDP growth level, and decreases in growth rate of consumer price index and quarter-lagged equity prices have a positive significant effect on equity prices.

It is a well-known fact that asset price inflation is not easy to determine as other types of inflation. The main reason is that the bull runs in markets can be confusing and hard to differentiate from asset price bubbles, because an asset price deviates from its trend line in both situations. As a result, it is impossible to determine an external reference price, in order to understand if there is actually an inflation/bubble. Henceforth, a comparison of increases in asset prices and minimum wages gives us a better understanding of a possible asset price inflation/bubble. By using minimum wages as a proxy of disposable personal income, we also aim to show how equally the financial stimulus and relief packages are distributed among the population, after 2008-2009 global financial crisis and during COVID 19 pandemic. The reason for the decreasing stock purchasing power of minimum wage earners may be because the liquidity supply of financial stimulus packages benefit high-income earning individuals more than low-income individuals. As an outcome of the unequal distribution, individuals with higher income increase their savings by investing in assets, rather than spending, as most individuals with lower income would do. The positive relationship between increases in equity prices and credits given to non-financial sector shows us the level of financialization reached: The credits are used as a leverage to invest in equities.

Our results showing that loose monetary policy via money supply growth and credit expansion has significant contribution to stock prices booms, leads to the question about what central banks should do about it. Actually, there is already a debate in existing literature on this subject. For instance, Shibuya (1992) claims that as long as CPI and GDP deflator are stable, asset price inflation should not be taken as dangerous. On the other hand, Singh and Pattanaik (2012) suggest that consumer price index is not a healthy indicator of inflation trends as asset price inflation, and monetary authority should avoid credit bubbles and excess liquidity conditions, in order to prevent asset price bubbles. What both sides fail to take into account is the side effect on wealth distribution. Central banks and monetary policy authorities should take this negative side effect into consideration, and may establish a closer cooperation with other economic policy actors, in order to tackle this issue. 
INTERNATIONAL JOURNAL OF ACADEMIC RESEARCH IN ACCOUNTING, FINANCE AND

MANAGEMENT SCIENCES

Vol. 11, No. 3, 2021, E-ISSN: 2225-8329 @ 2021 HRMARS

Due to the well known problems of econometric identification, caution is nevertheless needed, wherever a causal interpretation is suggested. A further research could be applied to all thirty-eight members of OECD, and could focus on increases in different layers of income levels and different assets, such as housing.

\section{References}

Adalid, R., \& Detken, C. (2007). "Liquidity shocks and asset price boom/bust cycles", ECB Working Paper, No. 732.

Adam, K., \& Tzamourani, P. (2016). "Distributional consequences of asset price inflation in the Euro area". European Economic Review, 89, 172-192.

Andersson, F. N. (2011). "Monetary policy, asset price inflation and consumer price inflation". Economics Bulletin, 31(1), 759-770.

Assenmacher-Wesche, K., \& Gerlach, S. (2008). "Financial structure and the impact of monetary policy on asset prices". Swiss National Bank.

Bank of International Settlements. (2016). Credit to non-financial sector [Data file]. Retrieved from https://www.bis.org/statistics/totcredit.htm?m=6\%7C380\%7C669

Bank of International Settlements. (2017). Central bank policy rates [Data file]. Retrieved from https://stats.bis.org/statx/toc/CBP.html

Bernanke, B., \& Gertler, M. (2000). "Monetary policy and asset price volatility", No: w7559. National Bureau of Economic Research.

Bernanke, B. S., \& Gertler, M. (2001). "Should central banks respond to movements in asset prices?". American Economic Review, 91(2), 253-257.

Bernanke, B. S., \& Kuttner, K. N. (2005). "What explains the stock market's reaction to Federal Reserve policy?". The Journal of Finance, 60(3), 1221-1257.

Bordo, M. D., \& Wheelock, D. C. (2004). "Monetary policy and asset prices: a look back at past US stock market booms". No: w10704. National Bureau of Economic Research.

Borio, C., Kennedy, N., \& Prowse, S. D. (1994). "Exploring aggregate asset price fluctuations across counties, measurement, determinants, and monetary policy implications", BIS Economic Papers, No. 40.

Bruggeman, A. (2006). "Can excess liquidity signal an asset price boom?", BIS Autumn Economists' Meeting, 30-31 October, Basel.

Cecchetti, S. G., Genberg, H., Lipsky, J., \& Wadhwani, S. (2000). "Asset prices and central bank policy". Centre for Economic Policy Research.

Cecchetti, S. G., Genberg, H., \& Wadhwani, S. (2002). "Asset prices in a flexible inflation targeting framework". No: w8970. National Bureau of Economic Research.

Cecchetti, S. G., Schoenholtz, K. L. (2006). "Money, banking and financial markets”. Vol. 4, McGrawHill/Irwin.

Christiano, L., Motto, R., \& Rostagno, M. (2003). “The Great Depression and the Friedman-Schwartz Hypothesis", Journal of Money, Credit and Banking, 35(6), 1119-1197.

Collingro, F., \& Frenkel, M. (2020). "On the financial market impact of euro area monetary policy: A comparative study before and after the Global Financial Crisis". Global Finance Journal, 45.

Congdon, T. (2005). "Money and Asset Prices in Boom and Bust". The Institute of Economic Affairs, London. 
INTERNATIONAL JOURNAL OF ACADEMIC RESEARCH IN ACCOUNTING, FINANCE AND

MANAGEMENT SCIENCES

Vol. 11, No. 3, 2021, E-ISSN: 2225-8329 ๑ 2021 HRMARS

Dell'Ariccia, G., Laeven, L., \& Marquez, R. (2014). "Real interest rates, leverage, and bank risk-taking". Journal of Economic Theory, 149, 65-99.

Federal Reserve Economic Data. (1991). Monetary Aggregates, M3 [Data file]. Retrieved from https://fred.stlouisfed.org/tags/series?t=m3\%3Bmonetary+aggregates

Galí, J., \& Gambetti, L. (2015). "The effects of monetary policy on stock market bubbles: some evidence". American Economic Journal: Macroeconomics, 7(1), 233-57.

Geromichalos, A., Licari, J. M., \& Suárez-Lledó, J. (2007). "Monetary policy and asset prices". Review of Economic Dynamics, 10(4), 761-779.

Goodhart, C. (2001). "What weight should be given to asset prices in the measurement of inflation?". The Economic Journal, 111(472), 335-356.

International Labor Organization (1980). Statutory nominal gross monthly minimum wage [Data file]. Retrieved from:

https://www.ilo.org/shinyapps/bulkexplorer9/?lang=en\&segment=indicator\&id=EAR_4MMN _CUR_NB_A

Jorda, O., Schularick, M., \& Taylor, A. M. (2013). "When credit bites back". Journal of Money, Credit and Banking, 45(2), 3-28.

Lee, J. H. (2006). "Assessing an existence of bubble in housing prices", Working Paper, No: 248, Bank of Korea.

Nelson, E. (2003). "The future of monetary aggregates in monetary policy analysis", Journal of Monetary Economics, 50(5): 1029-1059.

Organization for Economic Co-operation and Development. (2019). Real minimum wage [Data file]. Retrieved from https://stats.oecd.org/Index.aspx?DataSetCode=RMW

Organization for Economic Co-operation and Development (2021). Broad money (M3) (indicator). https://doi.org/10.1787/1036a2cf-en (Accessed on 24 May 2021)

Organization for Economic Co-operation and Development (2021). Inflation (CPI) (indicator). https://doi.org/10.1787/eee82e6e-en (Accessed on 24 May 2021)

Organization for Economic Co-operation and Development (2021). Quarterly GDP (indicator). https://doi.org/10.1787/b86d1fc8-en (Accessed on 24 May 2021)

Panigirtzoglou, N., \& Scammell, R. (2002). "Analysts' earnings forecasts and equity valuations”, Bank of England Quarterly Bulletin, Spring, 59-66.

Patelis, A. D. (1997). "Stock return predictability and the role of monetary policy". The Journal of Finance, 52(5), 1951-1972.

Paul, P. (2020). "The time-varying effect of monetary policy on asset prices". Review of Economics and Statistics, 102(4), 690-704.

Rigobon, R., \& Sack, B. (2004). "The impact of monetary policy on asset prices". Journal of Monetary Economics, 51(8), 1553-1575.

Schwartz, A. J. (2003). "Asset price inflation and monetary policy". Atlantic Economic Journal, 31(1), 1-14.

Shigemi, Y. (1995). "Asset inflation in selected countries". Monetary and Economic Studies, Bank of Japan, 13, 89-130.

Singh, B., \& Pattanaik, S. (2012). "Monetary policy and asset price interactions in India: Should financial stability concerns from asset prices be addressed through monetary policy?". Journal of Economic Integration, 167-194. 
INTERNATIONAL JOURNAL OF ACADEMIC RESEARCH IN ACCOUNTING, FINANCE AND MANAGEMENT SCIENCES

Vol. 11, No. 3, 2021, E-ISSN: 2225-8329 @ 2021 HRMARS

Thorbecke, W. (1997). "On stock market returns and monetary policy". The Journal of Finance, 52(2), 635-654.

Trading Economics. (2021). Stock market [Data file]. Retrieved from https://tradingeconomics.com/stocks

Yao, S., Luo, D., \& Loh, L. (2013). “On China's monetary policy and asset prices". Applied Financial Economics, 23(5), 377-392. 